\title{
A call for consistency with the terms 'wetter' and 'drier' in climate change studies
}

\author{
Nina Roth ${ }^{1,2^{*}}$, Fernando Jaramillo ${ }^{1,2,3}$, Lan Wang-Erlandsson ${ }^{2,4}$, David Zamora ${ }^{5}$, \\ Sebastián Palomino-Ángel ${ }^{6,7}$ and Sara A. O. Cousins ${ }^{1,2}$
}

\begin{abstract}
Ongoing and future hydroclimatic changes have large environmental and societal impacts. In terrestrial ecosystems, these changes are usually described with the terms 'wetter' and 'drier', which refer to the change in the quantity and/ or presence of water, either as water fluxes or stocks. We conducted a literature review of almost 500 recent climate change studies to quantitatively investigate the consistency of the use of these terms across disciplines, regarding the hydroclimatic variables they are related to. We found that although precipitation is prevalently used to describe 'wetter' and 'drier' conditions, many other variables are also used to refer to changes in water availability between research fields, pointing to a varied perspective on the use of these terms. Some studies do not define the terms at all. In order to facilitate meta-analyses across disciplines, we therefore highlight the need to explicitly state which hydroclimatic variables authors are referring to. In this way, we hope that the terms 'wetter' and 'drier' used in scientific studies are easier to relate to hydroclimatic processes, which should facilitate the application by authorities and policy makers.
\end{abstract}

Keywords: Definitions, Hydroclimatic variables, Multidisciplinary, Ecosystems

\section{Difficult to synthesize 'wetting' and 'drying' effects} Climate change-induced alterations of the global hydrological cycle can have substantial impacts on local climate, ecosystems, and societies [1-6]. For example, reduced precipitation can cause droughts, higher temperatures can turn snowfall into rainfall, and increased runoff can lead to floods $[1,5,7,8]$. Such hydrological changes can affect society either directly, e.g., through catastrophic damage, or indirectly, e.g., through reduced crop productivity [4]. One of the main questions in climate change studies therefore is whether a specific region will increase or decrease its amount of water. This question is also related to the paradigm 'dry gets drier, wet gets wetter' [9], agreeing with the general concept of the intensification of the water cycle [4]. Hence, the terms

*Correspondence: nina.roth@natgeo.su.se

1 Department of Physical Geography, Stockholm University, Stockholm, Sweden

Full list of author information is available at the end of the article 'drier' and 'wetter' are now used widely across disciplines, with studies describing historical or future changes in water availability. Predictions of drier or wetter conditions should be communicated carefully and accurately both among scientists and to the public, especially to stakeholders and populations who depend directly on that water resource. An estimate of potentially drier conditions would motivate authorities to prepare for drought and reductions in the freshwater resource required for private households, industry, energy and agriculture sectors. On the contrary, an estimate of potentially wetter conditions appears to reduce the threat of expected catastrophic droughts, but can raise concern and awareness in the population to experience more flooding events and intense rains. However, confusion appears to be arising within the multidisciplinary climate change community because of the inconsistent use of the terms 'wetter' and 'drier' to describe changes in a broad range of hydroclimatic trends and their effects on ecosystems, agriculture, and water supply for societies [10-13].

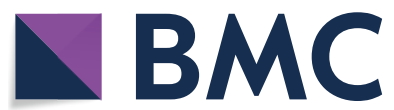

c) The Author(s) 2021. This article is licensed under a Creative Commons Attribution 4.0 International License, which permits use, sharing, adaptation, distribution and reproduction in any medium or format, as long as you give appropriate credit to the original author(s) and the source, provide a link to the Creative Commons licence, and indicate if changes were made. The images or other third party material in this article are included in the article's Creative Commons licence, unless indicated otherwise in a credit line to the material. If material is not included in the article's Creative Commons licence and your intended use is not permitted by statutory regulation or exceeds the permitted use, you will need to obtain permission directly from the copyright holder. To view a copy of this licence, visit http://creativeco mmons.org/licenses/by/4.0/. The Creative Commons Public Domain Dedication waiver (http://creativecommons.org/publicdomain/ zero/1.0/) applies to the data made available in this article, unless otherwise stated in a credit line to the data. 
It is worth noting that the 'dry gets drier, wet gets wetter' paradigm is mostly based on oceanic data and apparently does not hold for changes over land [9, 14-16]. Moreover, hydroclimatic patterns vary not only spatially (e.g., ocean vs. land, or small-scale vs. large-scale) [4, 1719], but also temporally (e.g., long-term totals vs. shortterm extremes, or dry vs. wet seasons) [20-22]. So it is not only the overall amount of a variable that matters, but also its spatial and temporal distribution. For example if a given yearly amount of precipitation is confined to only winter months (i.e., snow during dormant season), it has very different implications for the ecosystem compared to if it would fall during summer (i.e., rain during growing season), or within only a few days (i.e., extreme weather events).

In general, 'wetter' implies an increase in water fluxes such as precipitation and runoff or in water stocks such as soil moisture and surface water volume, while 'drier' implies the opposite. Although absolute hydroclimatic variables and their changes are interrelated by the conservation of water mass and energy, their magnitude of change may not be consistent [4, 23, 24]. For example, an increase in precipitation in time does not necessarily imply an increase in river water availability-if accompanied by a steep increase in evaporation by more thermal energy availability, runoff can in fact decrease [25, 26]. Therefore, based on changes in precipitation alone, it cannot be concluded that landscape conditions will become unambiguously 'wetter' or 'drier' [19, 25, 27].

In addition to this complexity in the global 'wetting' and 'drying' trends, we want to point out that there is another factor adding to uncertainty, which is the variability of meanings of the words 'wetter' and 'drier.' The same words are being used in the scientific literature to describe different processes, which makes it difficult for researchers to compare and synthesize results, and confusing for the wider audience to understand and communicate climate change effects correctly.

The problem of the multiple meanings of the terms 'wetter' and 'drier' is particularly evident when comparing different research fields. For example, in meteorology, droughts are usually characterized by precipitation, in agricultural studies by soil moisture, and in surface hydrology by water storage or runoff $[23,28,29]$. A recent literature review has pointed out how even within one research field, in this case ecology, droughts are characterized in many different ways (e.g., a decrease in either precipitation, soil moisture or streamflow) [30]. Although the water variable related to the 'dry gets drier, wet gets wetter' concept is usually the residual of precipitation minus evaporation or evapotranspiration $[15,20]$, there are also cases where it is related to drought indices or soil moisture [16, 31]. In a broader context, our work fits well into the general call for a common terminology within climate science [32] and ecology [33]. By quantifying the differences between research fields, we hope to add new insights to this discussion.

\section{Scoping review}

In order to shed light on the discrepant meanings of 'wetter' and 'drier' in climate change studies, we performed a literature review and investigated how different environmental research fields define those two words. In the search engine Scopus, we searched for the keywords 'drier', 'wetter' and 'climate change' in the title, abstract and keywords of all articles that were published between 2012 and 2017 under the two subject areas 'Agricultural and Biological Sciences' and 'Earth and Planetary Sciences'. This search returned 507 articles, from which 20 records were excluded to restrict our study to only studies fully available in English and published in peer reviewed journals. We read the abstract of each article to understand the context, and then searched for the words 'drier' and 'wetter' in the text using the search function. Each time one of these two words came up, we read the surrounding paragraphs to determine which hydroclimatic variables the terms 'wetter' or 'drier' are relating to in the given context. Usually, it became evident within the same paragraph, but if not, we expanded reading also the next paragraphs until we found the information we were looking for. We had pre-defined several hydroclimatic variables that we had expected to find, and noted others that we had not pre-defined and were rarely used (full list of variables in Table 1). If an article used several hydroclimatic variables to describe 'wetter' or 'drier', we noted down all of the variables.

Moreover, we noted the temporal extent of the study, grouped into 4 categories ( $<1$ year, $1-5$ years, $6-20$ years and $>20$ years), as well as its spatial extent, grouped into three categories: local (i.e., just one field site), regional (i.e., from landscape scale to biomes) and global. Due to the great variety of research fields, we decided to not quantify the spatial categories, but to categorize them based on the context (e.g., 'local' in a plant ecological study is much smaller than 'local' in an atmospheric science study). Finally, we grouped all articles into 18 different research fields, according to CiteScore, which were 'Agronomy and Crop Science,' 'Earth-Surface Processes', 'Geology', 'Animal Science and Zoology', 'Ecology', 'Geophysics,' 'Aquatic Science,' 'Ecology, Evolution, Behavior and Systematics', 'Oceanography', 'Archeology', 'Forestry', 'Paleontology', 'Archeology (arts and humanities)', 'General Agricultural and Biological Sciences', 'Plant Science', 'Atmospheric Science,' 'General Earth and Planetary Sciences' and 'Water Science and Technology'. A table with 
Table 1 Hydroclimatic variables used to describe 'wetter' and 'drier' conditions, based on 487 studies

\begin{tabular}{|c|c|}
\hline Variable & Explanation \\
\hline Precipitation & In liquid or solid form \\
\hline Soil moisture & Soil water content/potential/storage, available soil water \\
\hline Runoff & Both surface and subsurface \\
\hline Temperature & Only air temperature \\
\hline Evapotranspiration & Both actual and potential evapotranspiration \\
\hline Water table & Groundwater and surface water levels \\
\hline Proxies & Stalagmites, sediments (pollen, isotopes, molluscs, diatoms, charcoal, magnetic etc.), tree rings, corals, mammals, paleosols \\
\hline Not defined & Unclear how'wetter'and 'drier'should be understood in the context \\
\hline Other variables & $\begin{array}{l}\text { Variables that were rarely mentioned, e.g., vegetation/habitat type (like wet/dry forests), humidity (usually very vague), } \\
\text { water temperature, sea surface temperature, stream flow, salinity, radiation, snow water equivalent }\end{array}$ \\
\hline
\end{tabular}

the results of our scoping review can be found in Additional file 1 .

\section{'Wetter' and 'drier' are defined differently across research fields}

We found that environmental disciplines are defining 'wetter' and 'drier' differently. According to our literature study, precipitation is the main variable that all research fields (except for 'Geology') use to define 'wetter' and 'drier' conditions (Fig. 1), either on its own or in combination with other variables. However, for the remaining variables that can represent 'wetter' or 'drier' conditions, we found substantial differences within and between research fields. For example, temperature is mentioned mostly in 'Agronomy and Crop Science' and 'Ecology' (even though changes in temperature on their own cannot really imply that water availability is changing), evapotranspiration in 'Aquatic Science', soil moisture in 'Animal Science and Zoology', 'Ecology, Evolution, Behavior and Systematics' and 'Plant Science', and runoff in 'Water Science and Technology' and 'Earth-Surface Processes'. In a small number of studies, mostly in 'Archeology (arts and humanities), 'Geology', 'Plant Science' and 'Water Science and Technology', water table is the variable defining 'wetter' and 'drier' conditions.

Proxies like tree rings or lake sediments are commonly used in fields such as 'Paleontology' and 'Archeology' to infer historic climatic conditions and do not directly relate to any hydroclimatic variables, and they generally cannot disentangle signals of moisture from those of temperature [34]. In addition to the variables that we had pre-defined, we also found other, rarely mentioned variables relating to 'wetter' or 'drier', such as salinity, streamflow, humidity, habitat type or radiation. In surprisingly many research articles the words 'wetter' and 'drier' are not defined or related to any hydroclimatic variable at all, primarily in 'General Earth and Planetary Sciences' and 'Geology'.
We also analysed how many hydroclimatic variables are used to define 'wetter' and 'drier' conditions per article. In most cases, authors refer to only one variable (mostly precipitation) to describe 'wetter' or 'drier' conditions, although there can be up to four variables being used simultaneously (Fig. 2). Notably, even in cases where only one variable is characterizing 'wetter' and 'drier' conditions, there is no consistency among articles.

Another important aspect is that the temporal ( $<1$ year, $1-5$ years, $6-20$ years, $>20$ years) and spatial scales (local, regional, global) vary among studies. Reference conditions for a study area to be 'wetter' or 'drier' can relate either to a change in time or in space, meaning that measurements can be taken either over a certain timespan, at two points in time, during reoccurring wet and dry seasons, along a spatial gradient or to compare wetter and drier sites. At regional and global scales, precipitation and evapotranspiration are mentioned more often, since these measurements can easily be derived from weather stations; whereas at local scales (i.e., catchment scale or smaller), soil moisture and water table based on field studies are more commonly used (Fig. 3b). Proxy samples taken at local scales (Fig. 3b) are often used in paleoclimate studies to represent a large temporal scale (Fig. 3a).

In addition to our quantitative analyses, we also noted other interesting patterns. In some cases it was impossible to disentangle temperature and precipitation, as they were used pairwise throughout the text. A typical example would be: "[...] as conditions become warmer and drier, populations presently adapted to cooler and wetter conditions may evolve to become more similar to those adapted to warmer and drier conditions." [35]. In other cases, the authors seemed to be aware of the ambiguity of the terms 'wetter' and 'drier. This could be seen for example when they used quotation marks, e.g., in "We also constructed a throughfall-interception experiment to create "wetter" and "drier" plots." [36] or in "[...] 


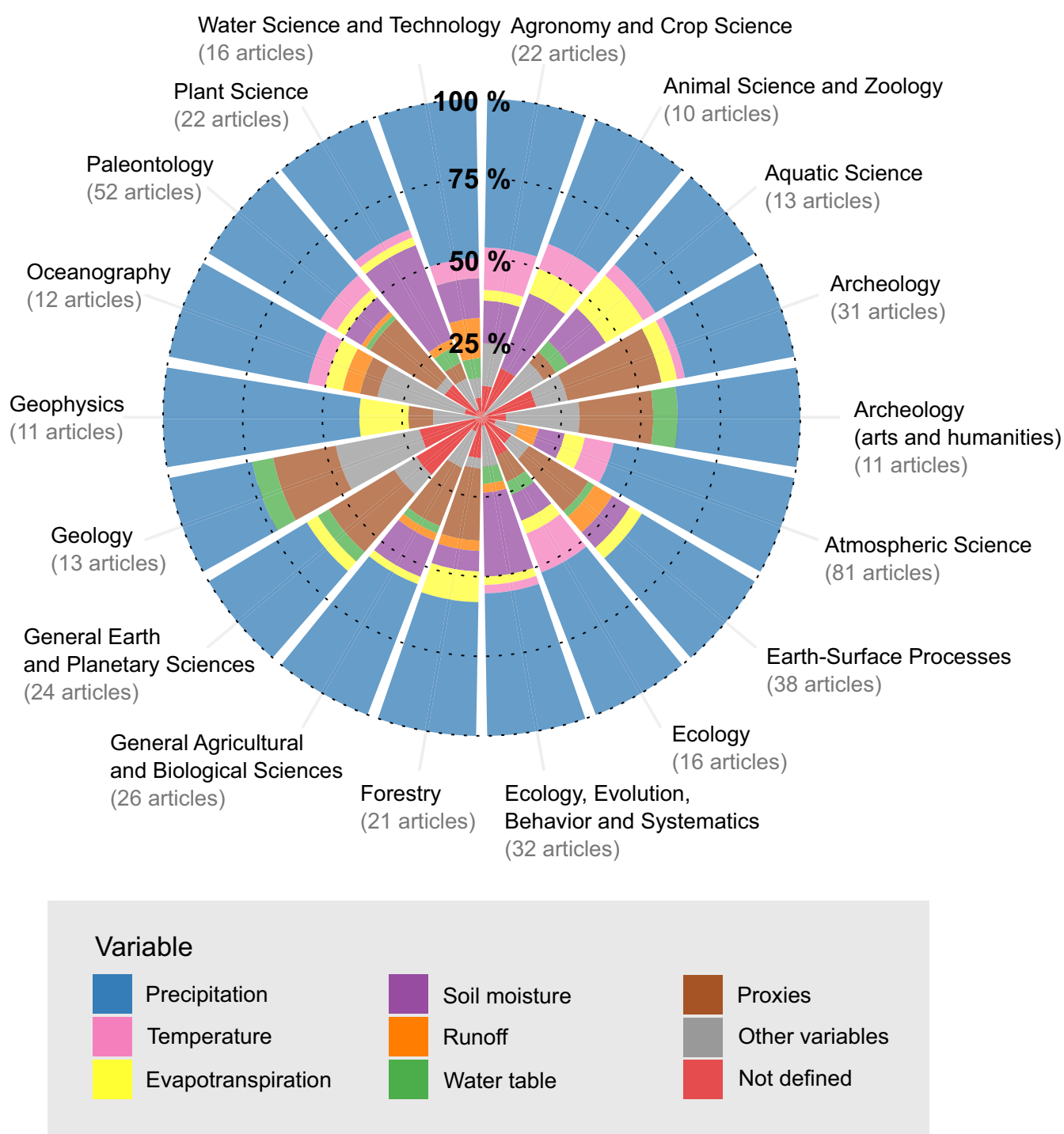

Fig. 1 Hydroclimatic variables used to define 'wetter' and 'drier' conditions. We analysed 487 climate change studies published between 2012 and 2017 and sorted them by research discipline. Only research fields that comprise 10 or more articles are shown. One article can use none, one or several hydroclimatic variables to define 'wetter' and 'drier' conditions

precipitation and drought treatments shifted natural soil moisture gradients to "wetter" and "drier", respectively." [37]. Some authors defined these terms particularly clearly, e.g., in "[...] July was the wettest month in respect of precipitation and a drier one in respect of runoff [...]" [38] or in "For all three variables there is a clear increase over time in the total area becoming permanently wetter or drier than the historical mean." [23].

Our suggestions for a more precise communication In conclusion, we found no consistency on what constitutes 'wetter' or 'drier' conditions among the research fields we examined. The varying, sometimes even lacking, definitions of these terms obstruct synthesizing results from different climate change studies. It also hinders a clear communication of socially relevant climate change effects and adaptation strategies for communities and ecosystems. In order to make informed predictions on the effects of climate change, it is necessary to be able to compare between different research fields, geographical regions as well as temporal and spatial scales.

Given the broad range of research fields examining drying and wetting effects of climate change, it seems unreasonable to try to standardize the definitions of 'wetter' and 'drier'. However, we have several suggestions that might facilitate synthesizing results 


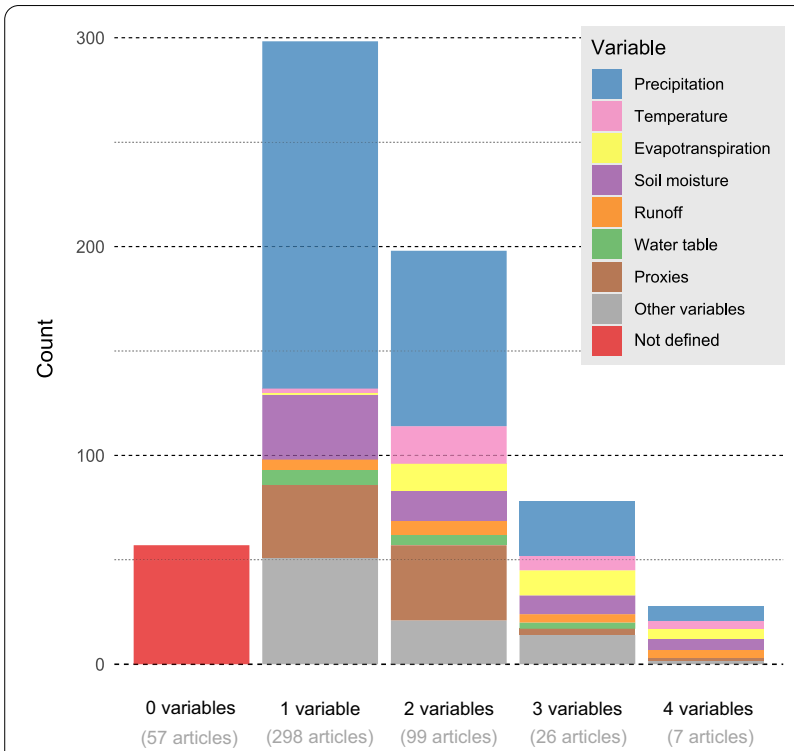

Fig. 2 Count of different hydroclimatic variables used to define 'wetter' or 'drier' in 487 climate change studies published between 2012 and 2017, sorted by the number of variables per article. 57 studies did not define 'wetter' or 'drier' at all (i.e., 0 variables) from different studies. First, it should be stated clearly which hydroclimatic variable(s), spatial scale and temporal scale the authors are referring to when mentioning the terms 'wetter' or 'drier'. This information should be included in the method section of the paper, not in the supplementary material, so that it is easily accessible. As we found in our literature review, several studies used those terms without further explanation-this should be avoided. A clear definition of the terms 'wetter' and 'drier' would make the studies more quantifiable and comparable. Secondly, since the terms 'wetter' and 'drier' are referring to a process, it should be clarified which original state that change is being compared to. Thirdly, adjectives identifying water availability should not be supplanted by those of energy availability (i.e., temperature) and it should be possible to disentangle the effects of precipitation from temperature. Finally, when synthesizing several studies from different research fields, one has to be aware that 'wetter' or 'drier' might refer to different hydroclimatic processes, and might therefore have different effects on the ecosystem. For example 'drier' in the sense of decreased precipitation can have different effects than 'drier' meaning a lower water table, or increased salinity. Furthermore, 'drier' during a time of the season when plants or fields are dormant might not necessarily affect growth or yield. Therefore, there is a need to be cautious when drawing conclusions about 'drying' or 'wetting' effects across research fields, and examine

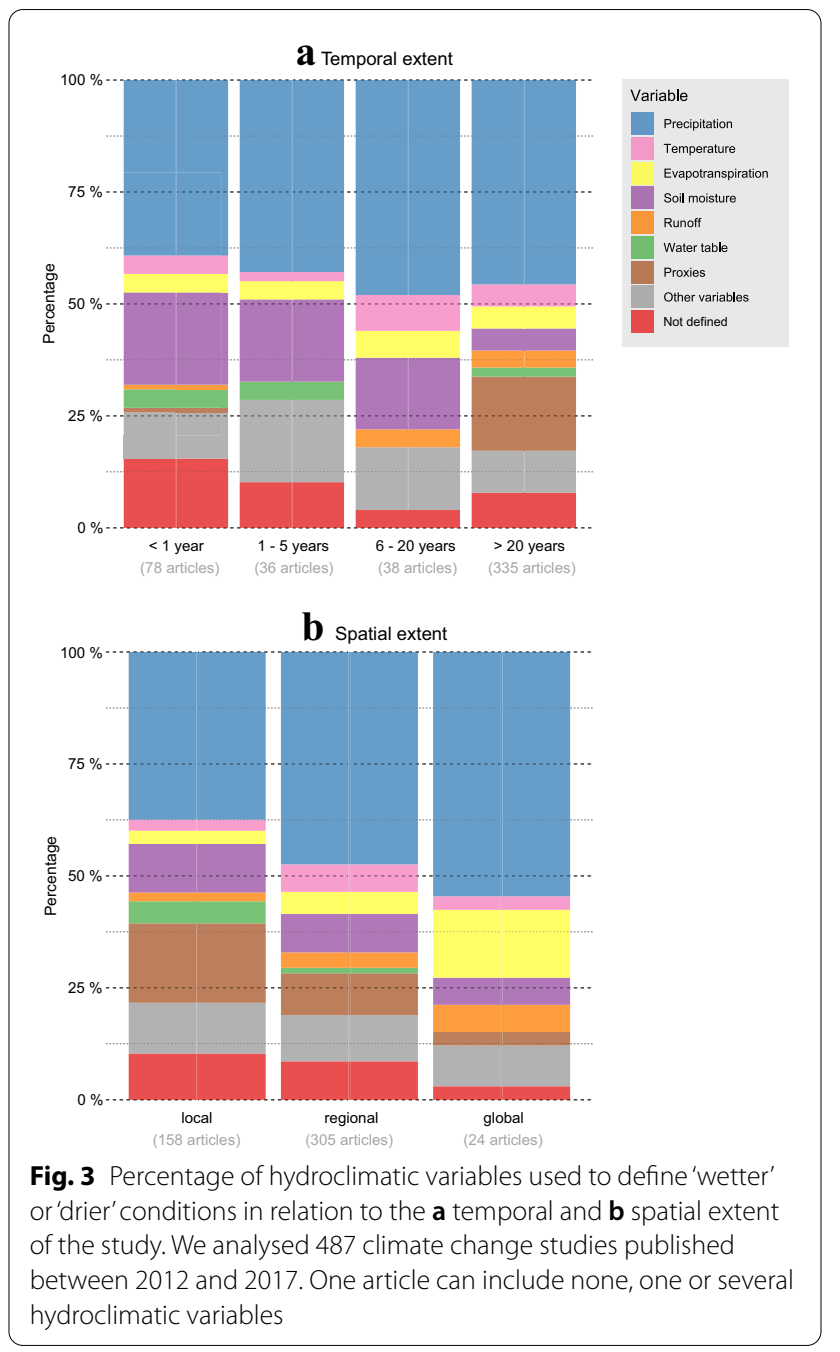

carefully if it is really the same process that is being described. Our recommendations are summarized in Box 1.

\section{Box 1 Suggestions for more consistency with the terms 'wetter' and 'drier' in climate change studies Checklist for using 'wetter' and 'drier'}

- Which hydroclimatic variable/s is/are meant?

- What is the spatial and temporal scale of the study? - Which original state are 'wetter' and/or 'drier' compared to?

- Are the effects of precipitation distinguishable from those of temperature?

- When synthesizing results from different studies, are the same hydroclimatic processes investigated, i.e., are the effects on ecosystems comparable? 
Our recommendations are aimed primarily at fellow researchers. If authors of climate change studies are clear about how they define 'wetter' and 'drier', it will be easier to synthesize findings of multiple articles across research fields. Summarized findings can then serve as an accurate and convincing basis for public and private stakeholders to communicate climate change effects and to base their decisions upon. This in turn should steer the public climate change debate towards a more comprehensible and effective discussion about impacts and adaptation.

\section{Supplementary Information}

The online version contains supplementary material available at https://doi. org/10.1186/s13750-021-00224-0.

Additional file 1: Extracted data from scoping review.

\section{Acknowledgements}

Not applicable.

\section{Authors' contributions}

NR helped developing the methodology, coordinated the literature review analysed the articles within the field 'Agricultural and Biological Sciences', analysed and visualised the results and wrote the original draft with input from all authors. FJ and SAOC conceived the original idea. FJ and LW helped developing the methodology. FJ, LW, DZ and SP analysed the articles within the field 'Earth and Planetary Sciences'. SAOC also supervised NR. All authors read and approved the final manuscript.

\section{Funding}

Open access funding provided by Stockholm University. NR, FJ, DZ, SP, SAOC: Bolin Centre for Climate Research at Stockholm University, LW: ERC-2016-ADG 743080 (ERA project).

\section{Availability of data and materials}

All data generated or analysed during this study are included in this published article [and its Additional information files].

\section{Declarations}

Ethics approval and consent to participate

Not applicable.

\section{Consent for publication}

Not applicable.

\section{Competing interests}

The authors declare that they have no competing interests.

\begin{abstract}
Author details
${ }^{1}$ Department of Physical Geography, Stockholm University, Stockholm, Sweden. ${ }^{2}$ Bolin Centre for Climate Research, Stockholm, Sweden. ${ }^{3}$ Baltic Sea Centre, Stockholm University, Stockholm, Sweden. ${ }^{4}$ Stockholm Resilience Centre, Stockholm University, Stockholm, Sweden. ${ }^{5}$ Civil and Agricultural Department, Universidad Nacional de Colombia, Bogotá, Colombia. ${ }^{6}$ Facultad de Ingeniería, Universidad de San Buenaventura, Medellín, Colombia. ${ }^{7}$ Facultad de Ingeniería, Universidad de Medellín, Medellín, Colombia.
\end{abstract}

Received: 28 January 2021 Accepted: 20 March 2021

Published online: 01 April 2021

\section{References}

1. Oki T, Kanae S. Global hydrological cycles and world water resources. Science. 2006:313(5790):1068-72.

2. Young G, Demuth S, Mishra A, Cudennec C. Hydrological sciences and water security: an overview. Proc IAHS. 2015;366:1-9.

3. Diffenbaugh NS, Giorgi F. Climate change hotspots in the CMIP5 global climate model ensemble. Clim Chang. 2012;114(3):813-22.

4. Huntington TG. Evidence for intensification of the global water cycle: review and synthesis. J Hydrol. 2006:319(1):83-95.

5. Milly PCD, Wetherald RT, Dunne KA, Delworth TL. Increasing risk of great floods in a changing climate. Nature. 2002;415(6871):514-7.

6. Rawlins MA, Steele M, Holland MM, Adam JC, Cherry JE, Francis JA, et al. Analysis of the arctic system for freshwater cycle intensification: observations and expectations. J Clim. 2010;23(21):5715-37.

7. Berghuijs WR, Woods RA, Hrachowitz M. A precipitation shift from snow towards rain leads to a decrease in streamflow. Nature Clim Chang. 2014;4(7):583-6.

8. Wada Y, van Beek LPH, Wanders N, Bierkens MFP. Human water consumption intensifies hydrological drought worldwide. Environ Res Lett. 2013:8(3):034036

9. Greve P, Orlowsky B, Mueller B, Sheffield J, Reichstein M, Seneviratne SI. Global assessment of trends in wetting and drying over land. Nat Geosci. 2014;7(10):716-21.

10. Trenberth KE. Changes in precipitation with climate change. Clim Res. 2011:47(1-2):123-38

11. Chou C, Chiang JCH, Lan C-W, Chung C-H, Liao Y-C, Lee C-J. Increase in the range between wet and dry season precipitation. Nat Geosci. 2013;6(4):263-7.

12. Held IM, Soden BJ. Robust responses of the hydrological cycle to global warming. J Clim. 2006;19(21):5686-99.

13. Liu C, Allan RP. Observed and simulated precipitation responses in wet and dry regions 1850-2100. Environ Res Lett. 2013;8(3):034002.

14. Sun F, Roderick ML, Farquhar GD. Changes in the variability of global land precipitation. Geophys Res Lett. 2012;39(19):L19402.

15. Byrne MP, O'Gorman PA. The response of precipitation minus evapotranspiration to climate warming: why the "wet-get-wetter, dry-get-drier" scaling does not hold over land. J Clim. 2015;28(20):8078-92.

16. Feng $\mathrm{H}$, Zhang M. Global land moisture trends: drier in dry and wetter in wet over land. Sci Rep. 2015;5:18018

17. Roderick M, Sun F, Lim WH, Farquhar G. A general framework for understanding the response of the water cycle to global warming over land and ocean. Hydrol Earth Syst Sci. 2014;18:1575-89.

18. Allan RP, Liu C, Zahn M, Lavers DA, Koukouvagias E, Bodas-Salcedo A. Physically consistent responses of the global atmospheric hydrological cycle in models and observations. Surv Geophys. 2014;35(3):533-52.

19. Lavers DA, Ralph FM, Waliser DE, Gershunov A, Dettinger MD. Climate change intensification of horizontal water vapor transport in CMIP5. Geophys Res Lett. 2015;42(13):5617-25.

20. Donat MG, Lowry AL, Alexander LV, O'Gorman PA, Maher N. More extreme precipitation in the world's dry and wet regions. Nat Clim Chang 2016;6(5):508-13.

21. Gloor M, Brienen RJW, Galbraith D, Feldpausch TR, Schöngart J, Guyot J-L, et al. Intensification of the Amazon hydrological cycle over the last two decades. Geophys Res Lett. 2013;40(9):1729-33.

22. Ziegler AD, Sheffield J, Maurer EP, Nijssen B, Wood EF, Lettenmaier DP. Detection of intensification in global- and continental-scale hydrological cycles: temporal scale of evaluation. J Clim. 2003;16(3):535-47.

23. Dirmeyer PA, Yu L, Amini S, Crowell AD, Elders A, Wu J. Projections of the shifting envelope of water cycle variability. Clim Change. 2016;136(3):587-600.

24. Labat D, Goddéris Y, Probst JL, Guyot JL. Evidence for global runoff increase related to climate warming. Adv Water Resour. 2004;27(6):631-42.

25. Bosson E, Sabel U, Gustafsson LG, Sassner M, Destouni G. Influences of shifts in climate, landscape, and permafrost on terrestrial hydrology. J Geophys Res Atmos. 2012;117(5):1-12.

26. Katul GG, Oren R, Manzoni S, Higgins C, Parlange MB. Evapotranspiration: a process driving mass transport and energy exchange in the soil-plantatmosphere-climate system. Rev Geophys. 2012;50(3):RG3002.

27. Sherwood S, Fu Q. A drier future? Science. 2014;343(6172):737-9. 
28. Dracup JA, Lee KS, Paulson EG. On the definition of droughts. Water Resour Res. 1980;16(2):297-302.

29. Wilhite DA, Glantz MH. Understanding: the drought phenomenon: the role of definitions. Water Int. 1985;10(3):111-20.

30. Slette IJ, Post AK, Awad M, Even T, Punzalan A, Williams S, et al. How ecologists define drought, and why we should do better. Glob Change Biol. 2019;25(10):3193-200.

31. Hu Z, Chen X, Chen D, Li J, Wang S, Zhou Q, et al. "Dry gets drier, wet gets wetter": a case study over the arid regions of central Asia. Int J Climatol. 2019;39(2):1072-91.

32. Bowman TE, Maibach E, Mann ME, Moser SC, Somerville RCJ. Creating a common climate language. Science. 2009;324(5923):36-7.

33. Herrando-Pérez S, Brook BW, Bradshaw CJA. Ecology needs a convention of nomenclature. Bioscience. 2014;64(4):311-21.

34. Linderholm HW, Nicolle M, Francus P, Gajewski K, Helama S, Korhola A, et al. Arctic hydroclimate variability during the last 2000 years: current understanding and research challenges. Clim Past. 2018;14(4):473-514.
35. Schneider HE, Mazer SJ. Geographic variation in climate as a proxy for climate change: forecasting evolutionary trajectories from species differentiation and genetic correlations. Am J Bot. 2016;103(1):140-52.

36. Eller AS, Young LL, Trowbridge AM, Monson RK. Differential controls by climate and physiology over the emission rates of biogenic volatile organic compounds from mature trees in a semi-arid pine forest. Oecologia. 2016;180(2):345-58.

37. Krab EJ, Cornelissen JHC, Berg MP. A simple experimental set-up to disentangle the effects of altered temperature and moisture regimes on soil organisms. Methods Ecol Evol. 2015;6(10):1159-68.

38. Banasik K, Hejduk L. Long-term changes in runoff from a small agricultural catchment. Soil Water Res. 2012;7(2):64-72.

\section{Publisher's Note}

Springer Nature remains neutral with regard to jurisdictional claims in published maps and institutional affiliations.
Ready to submit your research? Choose BMC and benefit from:

- fast, convenient online submission

- thorough peer review by experienced researchers in your field

- rapid publication on acceptance

- support for research data, including large and complex data types

- gold Open Access which fosters wider collaboration and increased citations

- maximum visibility for your research: over $100 \mathrm{M}$ website views per year

At $\mathrm{BMC}$, research is always in progress.

Learn more biomedcentral.com/submissions 